
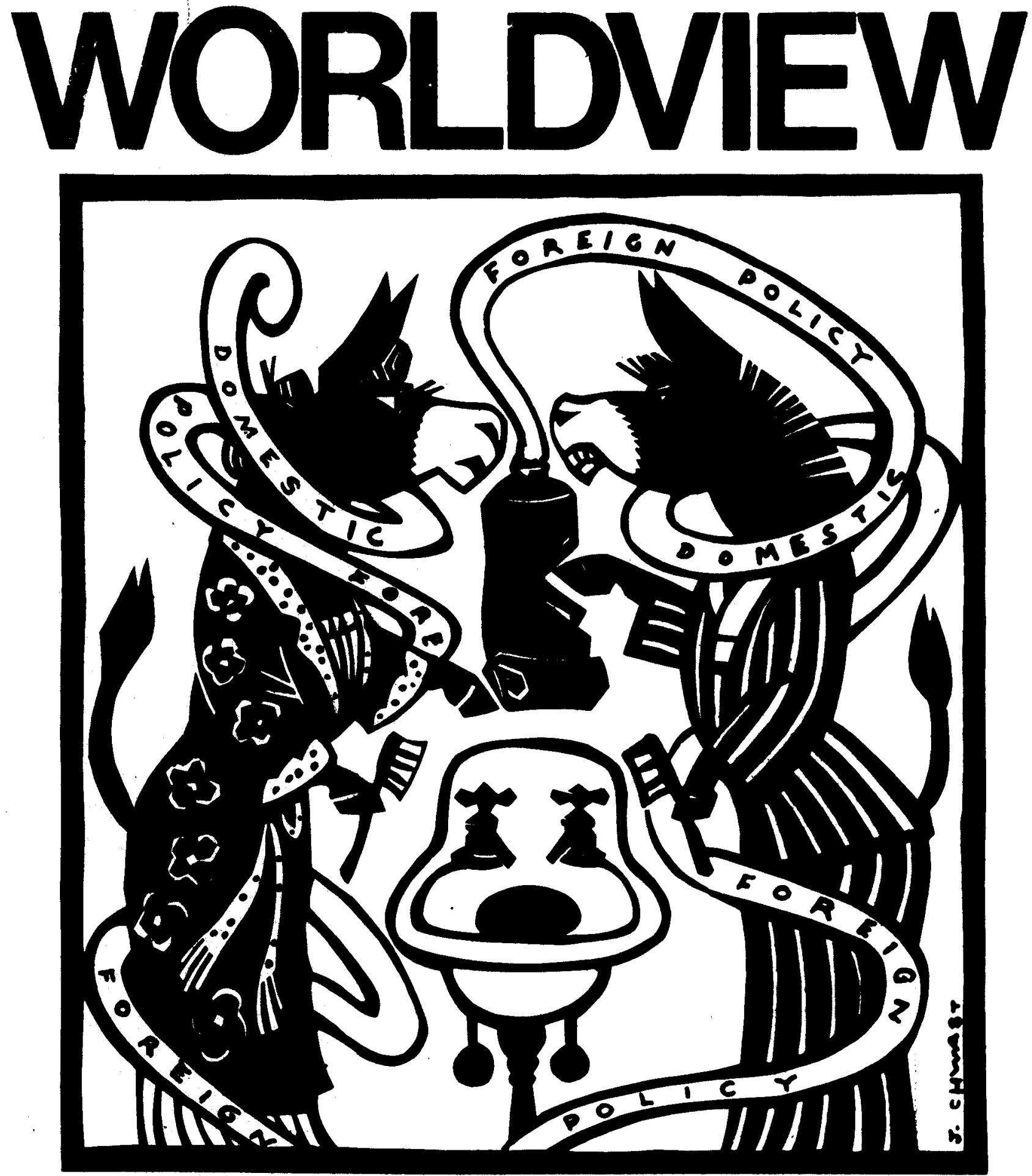

\title{
A DEMOCRATIC HOUSE DIVIDED
}

ROSS K. BAKER

MACHIAVELLI IN AMERICA - HENRY STEELE COMMAGER SOCIALISM \& THE NEW SPAIN - GARY PREVOST

BOOKS: Arnold Zeitlin on Stalemate in Afghanistan

Stefan Leader on Arming the Stratosphere

Walter Ashley on Prescriptions for Economic IIIs 

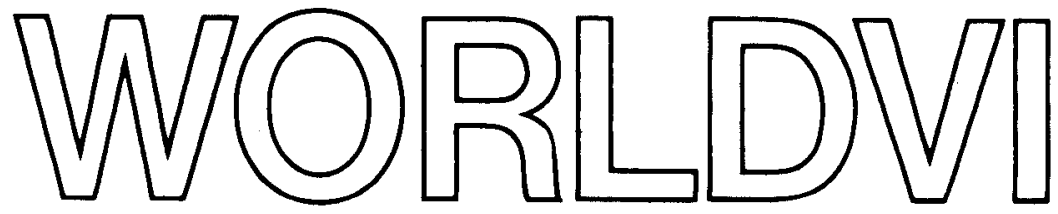

VOLUME 26. NUMBER 8

\section{EDITOR \\ John Tessitore \\ MANAGING EDTTOR Susan Woolison \\ LITERARY EDITOR John Becker \\ ASSOCIATE EDTORS \\ Mark A. Bruzonsky \\ Wilson Carey McWilliams \\ CONTRIBUTING EDITORS \\ Kofi Awoonor \\ Ross K. Baker \\ Robert W. Barnett \\ Gerald Freund \\ Robert C. Good \\ Michael Novak \\ Wolfhart Pannenberg \\ Gary A. Sledge \\ EDITORIAL INTERNS \\ Emily J. Rechnitz \\ Matthew T. Whedon \\ DESIGN CONSULTANT \\ Robert W. Powell \\ BUSINESS MANAGER \\ Eva Kluke \\ EDITORIAL BOARD \\ William J. Barnds (on leave) \\ Eugene B. Borowitz \\ Noel J. Brown \\ Robert F. Drinan, S.J. \\ James Finn \\ J. Bryan Hehir \\ Robert J. Myers \\ Richard John Neuhaus \\ Paul Ramsey \\ Seymour Siegel \\ Paul Sigmund \\ Kenneth $W$. Thompson}

\section{ARTICLES}

Machiavelli in the New World Henry Steele Commager

The Bipartisan Trap Ross $K$. Baker

4

The New Spain Gary Prevost ............................. 19

\section{EXCURSUS}

Toughing It Out in Britain Trevor Fishlock ................. 13

A Larger Role for Japan Gerald Hyman ...................... 14

A Strategic Precedent Walter $C$. Clemens, Jr.................. 15

The Moral High Ground Robert J. Myers ...................... 16

\section{COLUMNS}

Under Cover: The British Election \& the Politics of Dignity Wilson Carey McWilliams ..................... 2

Listening In ...................................... 11

U.N. Watch Stephen $S$. Fenichell ....................... 18

Current Account: Scapegoating Japan Benjamin J. Cohen .......... 22

\section{BOOKS}

The New high Ground: Strategies and Weapons of Space-Age War.

by Thomas Karas Stefan Leader.

Afghani. in and the Soviet Union, by Henry S. Bradsher

$$
\text { Arnold Zeitlin. }
$$

The Next American Frontier, by Robert B. Reich: The Next

Economy, by Paul Hawken Walter E. Ashley.

To End War, by Robert Woito; How Wars End, by Sydney D

Bailey Terry Nardin

The Health Revolution in Cuba, by Sergio Diaz-Briquets

George A. Silver.

Mexico: Development Strategies for the Future, by Denis Goulet David D'Arcy.

Third World Multinationals, by Louis T. Wells, Jr

Stephan Haggard

Cover Art: Jacqueline Chwast

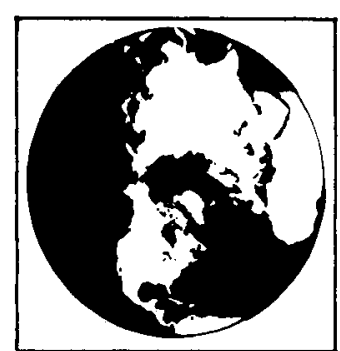

25thANNIVERSARY
WORLDVIEW is published monthly by the Council on Religion and International Allars

Subscription- $\$ 19.95$ a year; $\$ 37$ for 2 years. $\$ 53$ for 3 years Student rate $\$ 995$ per year Add $\$ 500$ pe year for overseas postage. Second-class postage paid at New York $N Y$ and at additional entry oftuces (ISSN 0084-2559)

Opinions expressed in WORLDVIEW are those of the authors and nol necessarily of the Council on Reli gion and international Aftairs. Copyright 1983 Council on Religion and International Aftairs a publicly supponted organization of the type described under sections $509(a)(1)$ and $170(b)(a)(A)(v)$ of the Inteme Revenue Code. Unsolicited manuscripts must be accompanied by a stamped sell-addressed retum en. velope. Letters to the Editor must include signature and address

Editorial \& Business \& Advertising Offices 170 E 64 Street. New York $N Y$ 10021 [212/838-4120] Sub scription Otfice and Change of Address WORLDVIEW. PO Box 1935 Marion Onio 43305 